\title{
MEMBANGUN SISTEM INFORMASI PENGOLAHAN DATA TABUNGAN SISWA BERBASIS WEB
}

\author{
Dewi Triyanti ${ }^{1}$, Tendi Dermawan ${ }^{2}$ \\ Teknik Informatika ${ }^{1}$, Manajemen Informatika ${ }^{2}$ \\ AMIK Dian Cipta Cendikia Pringsewu \\ Jl. Ahmad Yani No. 134 Sidoharjo - Pringsewu \\ Email: Dewi3yanti.yhud@gmail.com, tendidermawan3@gmail.com.
}

\begin{abstract}
ABSTRAK
Pemanfaatan teknologi informasi oleh sebuah lembaga organisasi dapat mempercepat pengaksesan informasi, ketepatan pengaksesan informasi, ketepatan waktu penyajian dan menghasilkan informasi yang akurat serta dapat memberikan pelayanan yang efektif dan efisien, system informasi berbasis web adalah system yang sering digunakan oleh instansi ataupun lembaga organisasi untuk menyampaikan informasi- informasi.
\end{abstract}

Dalam pembuatan sistem berbasis web, peneliti menggunakan metode Web Development Life Cycle (WDLC), dima dalam tahapan perancangan menggunakan Usecase Diagram, Class Diagram, Activity Diagram dan struktul Table. kemudaian software ataupun perangkat lunak yang digunakan adalah Xampp, MySQL, Adobe Photoshop CS, SablimText.

Hasil dari penelitian ini adalah memberikan solusi kepada SMK Islam Nurul Iman agar mengganti sistem yang masih manual ke sistem berbasis web, sehinggadengan menggunakan Web ini akan mempermudah dalam menangani transaksi tabungan, pencarian data tabungan, memasukkan data transaksi penyetoran dengan jumlah transaksi yang banyak, meminimalisir hilang nya buku tabungan siswa, dengan ada nya sistem ini juga para siswa atau orang tua dapat mentranfer ke rekening pihak sekolah sesuai yang tertera pada sistem tabungan, dan juga orang tua siswa dapat melihat riwayat/jumlah saldo tabungan anak nya.

Kata Kunci : Teknologi Informasi, Web Development Life Cycle, Tabungan, Siswa.

\section{ABSTRACT}

The use of information technology by an organization can accelerate the access of information, the accuracy of access to information, the timeliness of presentation and produce accurate information and can provide effective and efficient services, web-based information systems are systems that are often used by agencies or organizations to convey information - information.

In making a web-based system, researchers used the Web Development Life Cycle (WDLC) method, where in the design phase it used a Use case Diagram, Class Diagram, Activity Diagram and Structural Table. Then the software or software used is Xampp, MySQL, Adobe Photoshop CS, SablimText.

The results of this study are to provide a solution to Islamic Nurul Iman Vocational School to replace the system that is still manual to a web-based system, so that by using this website it will be easier to handle savings transactions, search for savings data, enter deposit transaction data with a large number of transactions, minimize lost the student savings book, with this system also the students or parents can transfer to the school account as stated in the savings system, and also the student's parents can see the history / amount of the child's savings balance.

Keywords: Information Technology, Web Development Life Cycle, Savings, Student.

1. PENDAHULUAN

Perkembangan teknologi informasi tidak dipungkiri semakin cepat dan bervariasi seiring 
berjalannya waktu dan berkembangnya zaman. Hampir semua aspek kehidupan memanfaatkan teknologi informasi ini untuk memenuhi kebutuhan yang ada, Tidak terkecuali dalam bidang pendidikan, Mulai dari tingkat dasar sampai dengan Perguruan Tinggi diharapkan bahkan diharuskan untuk menerapkan teknologi dalam proses belajar mengajar. Tidak hanya sampai disitu tetapi juga dalam pelayanan administrasi atau pelayanan lainnya yang berhubungan dengan para siswa dan para pengajar pun demikian dengan tujuan mempermudah dalam proses belajar mengajar, proses pengolahan data sampai dengan disajikannya suatu laporan yang akurat.

SMK Islam Nurul Iman adalah salah satu lembaga pendidikan dibawah naungan dinas pendidikan Lampung Timur, Sekolah Menengah Kejuruan (SMK) Islam Nurul Iman lampung timur adalah sekolah kejuruan swasta yang memiliki tiga jurusan yaitu Rekayasa Perangkat Lunak (RPL), Bisnis Manajemen (Bismen) dan Pelayaran, Selain penyelenggaraan pendidikan juga mengadakan program-program lainnya yang sangat bermanfaat baik bagi kelangsungan sekolah, prestasi siswa maupun keuangan siswa, salah satunya adalah tabungan siswa.

Siswa kelas 10 Sekolah Menengah Kejuruan SMK Islam Nurul Iman sudah mulai diwajibkan untuk menabung dimana nantinya hasil dari tabungan tersebut untuk keperluan mendesak siswa dalam hal pembiayaan sekolah misalnya yang selama ini berjalan digunakan untuk pembayaran Sekolah, seperti rencana Study tour dan untuk bayaran lainnya Mengingat di sekolah swasta memang dibutuhkan biaya yang cukup besar karena tidak disubsidi menyeluruh oleh pemerintah.

Dalam proses penyetoran tabungan, siswa di wajibkan untuk menyerahkan buku tabungan dan uang ke admin, guna untuk di data dalam buku tabungan siswa dan di buku kas pengelola tabungan sebagai transaksi penyetoran.

Permasalahan yang sedang terjadi yaitu pencatatan transaksi masih manual sehingga bisa menyebabkan kesalahan dalam pencatatan data apa bila penyetoran dengan jumlah transaksi yang banyak, serta sering hilang nya buku tabungan siswa dan kurang nya tranparasi data bagi orang tua siswa. Sistem yang berjalan saat ini masih dikerjakan secara manual, pencatatan dan penyimpanan data ditulis di dalam buku, dan perhitungannya masih dikerjakan dengan alat bantu kalkulator. Pemanfaatan teknologi informasi oleh sebuah lembaga organisasi dapat mempercepat pengaksesan informasi, ketepatan pengaksesan informasi, ketepatan waktu penyajian dan menghasilkan informasi yang akurat serta dapat memberikan pelayanan yang efektif dan efisien.

Dari latar belakang diatas penulis bermaksud memberikan solusi kepada SMK Islam Nurul Iman agar mengganti sistem yang masih manual ke sistem berbasis web sehingga mempermudah dalam menangani transaksi tabungan, pencarian data tabungan, memasukkan data transaksi penyetoran dengan jumlah transaksi yang banyak, meminimalisir hilang nya buku tabungan siswa, dengan ada nya sistem ini juga para siswa atau orang tua dapat mentranfer ke rekening pihak sekolah sesuai yang tertera pada sistem tabungan, dan juga orang tua siswa dapat melihat riwayat/jumlah saldo tabungan anak nya.

\section{LANDASAN TEORI}

Berikut merupakan teori yang mendukung pembuatan Sistem Informasi Pengolahan Data Tabungan Siswa Berbasis Web pada SMK Islam Nurul Iman.

\subsection{Membangun Sistem Informasi}

Pembangunan sistem informasi merupakan hal yang penting dalam perkembangan sistem informasi. Berikut ini definisi pembangunan sistem informasi (Information System Development) menurut para ahli :

1. Kumpulan kegiatan para analis sistem, perancang, dan pemakai yang mengembangkan dan mengimplementasikan sistem informasi [1].

2. Proses membangun dan mengimplementasikan sistem informasi sedemikian rupa sehingga sistem informasi tersebut menjadi ada/diwujudkan[2].

3. Proses merencanakan, mengembangkan, dan mengimplementasikan sistem informasi dengan menggunakan metode, tehnik, dan alat bantu pengembangan tertentu.

\subsection{Sistem Informasi}

Sistem informasi adalah suatu bentuk sistem komunikasi di mana data direpresentasikan dan diproses sebagai bentuk memori sosial. Sistem informasi juga dapat dianggap sebagai bahasa semi formal yang mendukung orang dalam pengambilan keputusan dan tindakan. Maka sistem informasi merupakan fokus utama dari 
studi untuk disiplin sistem informasi dan organisasi informatika.

Sistem ini diselenggarakan informasi dari manusia, perangkat lunak, perangkat keras, jaringan komunikasi dan sumber data untuk mengumpulkan, mengubah, dan mendistribusikan informasi dalam sebuah organisasi. Jadi sistem informasi adalah suatu sistem dalam suatu organisasi yang mempertemukan kebutuhan pengolahan transaksi harian, mendukung operasi, kegiatan manajerial dan strategis dari suatu organisasi dan menyediakan pihak luar tertentu dengan laporan-laporan yang diperlukan.[3]

\subsection{Tabungan}

Tabungan merupakan salah satu dari berbagai macam produk perbankan yang paling banyak diminati oleh masyarakat, mulai dari kalangan pelajar, kalangan pengusaha, dan masyarakat umum lainnya Sebelum adanya perbankan masyarakat menyimpan uangnya dirumah, seperti di lemari maupun dibawah kasur. Dan dengan penyimpanan yang seperti itu sangat tidak efektif, karena memiliki resiko kehilangan yang tinggi. Dengan adanya perbankan yang menyediakan produk tabungan masyarakat sudah mulai tertarik untuk menabung dibank karena banyak keuntungan yang diperoleh, antara lain uang yang disimpan aman dan uang nasabah akan bertambah dengan adanya bunga bank

Menurut UU No 10 Tahun 1998 yang dimaksud dengan tabungan adalah simpanan yang penarikannya hanya dapat dilakukan menurut syarat-syarat tertentu yang disepakati, tetapi tidak dapat ditarik dengan cek, bilyet giro, dan atau alat lainnya yang dipersamakan dengan itu, sedangkan tujuan dari menabung adalah mengumpulkan dana dari masyarakat guna membiayai pembangunan dan menanamkan kebiasaan menabung dikalangan masyarakat.[4]

\subsection{Jenis-Jenis Tabungan}

Terdapat beberapa Jenis - Jenis tabungan yaitu sebagai berikut [5]:

1. Tabungan Konvensional

Tabungan konvensional adalah jenis tabungan yang dimiliki hampir oleh seluruh masyarakat Indonesia. Tabungan ini paling populer karena cara untuk mengajukannya mudah dan prosesnya sangat cepat. Saat anda ingin memiliki tabungan dan rekening baru, hari itu juga anda sudah bisa memiliki tabungan tersebut. Fasilitas yang didapatkan jika memiliki tabungan jenis ini adalah dapat menyimpan uang, menyetorkan uang, mengambil uang kapan saja, dan memeriksa aktivitas rekening koran. Saat anda menggunakan tabungan ini, setiap bulannya akan ditarik biaya administrasi sesuai dengan ketentuan dari pihak Bank tersebut. Tabungan konvensional ini juga sudah dijamin oleh LPS (lembaga penjamin simpanan), yang akan menjamin keamanan uang anda, sekalipun bank tersebut bangkrut.

2. Tabungan Berjangka

Selain tabungan konvensional, jenis tabungan lain yang disediakan oleh Bank tertentu adalah tabungan berjangka. Jika pada tabungan konvensional, anda bisa mengambil uang tabungan kapan saja anda perlu. Bberbeda dengan tabungan berjangka, anda tidak bisa mengambil uang tersebut setiap saat. Di mana pengambilan uang hanya bisa dilakukan sesuai jadwal kesepakatan. Untuk jangka waktu tabungan berjangka atau deposito ini, tersedia dalam jangka waktu 1 bulan, 3 bulan, 6 bulan hingga 12 bulan. Bunga yang dikenakan untuk deposito relatif tinggi, yaitu antara 3 persen hingga 7 persen.

3. Tabungan Haji Ibadah ke tanah suci.

Impian hampir semua orang yang beragama islam. Untuk memudahkan mewujudkan impian tersebut, bank juga menyediakan tabungan haji, untuk memudahkan nasabahnya berangkat haji dalam jangka waktu tertentu. Untuk jenis tabungan ini, biasanya nasabah diwajibkan untuk menyetor uang sekitar Rp 100 ribu hingga Rp 500 ribu per bulan. Saat uang yang ditabungkan sudah berhasil terkumpul sekitar Rp 25 juta - Rp 30 juta, anda sudah bisa mendaftar ke kementerian agama. Fasilitas yang diberikan untuk tabungan ini adalah asuransi jiwa dan asuransi kecelakaan diri.

4. Tabungan Investasi

Anda suka bermain saham? Tabungan ini cocok untuk anda. Umumnya tabungan ini digunakan untuk nasabah yang bertransaksi jual-beli saham. Tabungan ini bersifat untuk penampungan uang yang akan digunakan khusus untuk membeli saham dan juga menyimpan laba hasil transaksi saham tersebut.

\section{Tabungan Anak}


Anak-anak juga bisa memiliki tabungan sendiri. Adanya tabungan ini adalah untuk mengedukasi anak-anak agar belajar lebih hemat terhadap uang yang mereka miliki. Pihak Bank menyediakan tabungan khusus anak dengan tampilan yang menarik. Anakanak yang menabung dengan tampilan buku tabungan dan kartu ATM yang sesuai usia mereka, tentunya akan lebih senang dan semangat untuk menabung. Saldo setoran untuk tabungan anak juga cenderung ringan. Tabungan anak ini juga dilengkapi dengan fasilitas seperti mobile banking dan internet banking.

6. Tabungan Giro Tabungan

Giro adalah tabungan khusus untuk transaksi bisnis. Tabungan giro diutamakan untuk transaksi berbagai perusahaan. Tabungan ini ada dalam bentuk Cek dan Bilyet Giro. Catatan transaksinya, nasabah yang merupakan sebuah perusahaan ini tidak akan menerima buku rekening seperti nasabah biasa, namun Bank akan mengirim rekening Koran berisi daftar transaksi selama satu bulan.

\section{Tabungan Mata Uang Asing}

Biasanya tabungan jenis ini seperti investasi dengan menggunakan mata uang asing. Investasi mata uang asing cukup bermanfaat, karena saat terjadi kenaikan nilai mata uang negara tersebut, saat ditukarkan kita akan mendapat keuntungan dari investasi ini.

\subsection{Siswa}

Siswa atau anak didik adalah salah satu komponen manusiawi yang menempati posisi sentral dalam proses belajar-mengajar, dalam proses belajar mengajar, siswa sebagai pihak yang ingin meraih cita-cita memiliki tujuan dan kemudian ingin mencapainya secara optimal. Siswa akan menjadi faktor penentu, sehingga dapat mempengaruhi segala sesuatu yang diperlukan untuk mencapai tujuan belajarnya. Menurut kamus besar bahasa Indonesia pengertian siswa berarti orang, anak yang sedang berguru (belajar, bersekolah). Sedangkan menurut pasal 1 ayat 4 UU RI No. 20 tahun 2013. Mengenai sistem pendidikan nasional, dimana siswa adalah anggota masyarakat yang berusaha mengembangkan diri mereka melalui proses pendidikan pada jalur dan jenjang dan jenis pendidikan tertentu. Berdasarkan pendapat di atas dapat disimpulkan bahwa siswa adalah anak yang bersekolah untuk mengembangkan diri mereka.[6]

\subsection{Tabungan Siswa}

Dalam Jurnal Algoritma mengatakan bahwa tabungan siswa merupakan tabungan program pendidikan bagi para orang tua untuk mempersiapkan masa depan anak secara terencana, murah , aman dan pasti. (Purnama, 2014)[7]

\subsection{Tujuan Tabungan Siswa}

Menurut (Purnama, 2014) tujuan seseorang (siswa/wali murid) ingin menabung di sekolah ada dua, antara lain:

1. Untuk bisa mengumpulkan sejumlah dana tertentu pada masa yang akan datang. Contohnya seperti menabung untuk bisa membeli kebutuhan tertentu yang berkaitan dengan kegiatan yang ada di sekolah.

2. Hanya ingin menjadikan tabungan sebagai rekening penampungan dan bukan untuk benar - benar menabung.

\subsection{Web}

Website adalah kumpulan dari beberapa halaman web dimana informasi dalam bentuk teks, gambar, suara, dan lain-lain dipersentasikan dalam bentuk hypertext dan dapat diakses oleh perangkat lunak yang disebut dengan browser. Informasi pada sebuah website pada umumnya di tulis dalam format HTML. Informasi lainya disajikan dalam bentuk grafis (dalam format GIF,JPG,PNG,dll), suara (dalam format AU,WAV,dll), dan objek multimedia lainya (seperti MIDI, ShockwaveQuicktime Movie, 3D World,dll).Website merupakan fasilitas internet yang menghubungkan dokumen dalam lingkup lokal maupun jarak jauh. Dokumen pada website disebut dengan web page dan link dalam website memungkinkan pengguna bisa berpindah dari satu page ke page lain (hyper text), baik diantara page yang disimpan dalam server yang sama maupun server diseluruh dunia. Pages diakses dan dibaca melalui browser seperti Netscape Navigator atau Internet Exploler berbagai aplikasi browser lainnya.(Destiniar \& Dedi Irwansyah, 2012)[8].

\subsection{Metodelogi Pengembangan Sistem WDLC}

Web Development Life Cycle adalah gabungan dari dua metodologi sebelumnya yang dikenal sebagai System Development Life Cycle dan Prototyping WDLC menggunakan komponen dari setiap metodologi, mengkombinasikannya menjadi sebuah pendekatan baru yang akan mengurangi waktu pengembangan, menambah struktur untuk masalah yang tidak terstruktur, dan tetap 
melibatkan pengguna dalam keseluruhan Development Life Cycle. [9]

beberapa metode yang mendukung WDLC yaitu

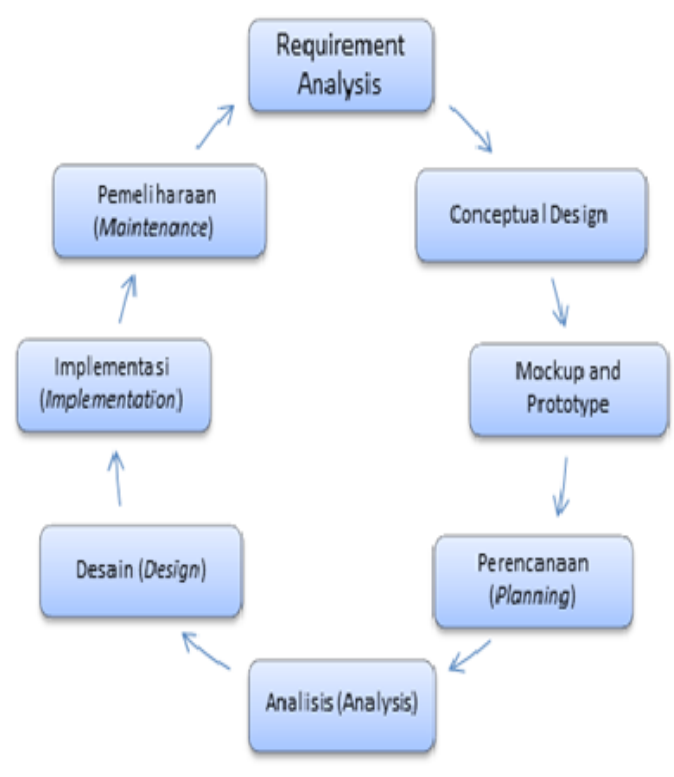

Gambar 1.1 Tahapan WDLC

\section{ANALISA DAN PERANCANGAN}

3.1 Analisa Kebutuhan Sistem

Sistem Informasi Tabungan Siswa yang dirancang ini SMK Islam Nurul Iman Lam-Tim dibangun dengan menggunakan teknologi berbasis Web untuk memudahkan akses informasi bagi pengguna agar informasi yang diberikan dapat digunakan dengan cepat dan mudah serta tranparan. Dalam pembuatan sistem ini diperlukan peralatan-peralatan tambahan atau kebutuhan teknologi antara lain yaitu kebutuhan perangkat keras (hardware), kebutuhan perangkat lunak (software), dan kebutuhan sumber daya manusia (brainware).

\subsection{Analisis Kebutuhan Sistem}

Masukan dari sistem informasi tabungan siswa pada Smk Islam Nurul Iman Lampung Timur adalah sebagai berikut:
1. Data kelas
2. Data siswa
3. Data tabungan
4. Data transaksi tabungan
5. Laporan tabungan siswa

3.3 Analisi Kebutuhan Output

Keluaran dari sistem informasi tabungan siswa adalah berupa informasi data siswa, data tabungan siswa, data transaksi tabungan, dan juga laporan tabungan siswa.

\subsection{Analisis Proses}

Proses yang terjadi pada sistem ini adalah proses pemberian informasi tentang jumlah saldo tabungan siswa dan juga transaksi menabung.

\subsection{Perancangan}

3.5.1 Alur Sistem Berjalan

Alur sistem yang berjalan pada SMK ISLAM NURUL IMAN LAMPUNG TIMUR desa Muara Gading Mas Dalam proses penyetoran tabungan siswa ini, bagi siswa baru di sekolah mereka mendaftar untuk di buatkanbuku tabungan ke admin dan memberikan uang untuk saldo awal mereka di tabungan. Bagi siswa yang sudah memiliki buku tabungan mereka menyerahkan buku tabungan dan uang ke admin tabungan untuk ditulis dibuku tabungan siswa dan di buku kas pengelola tabungan sebagai transaksi penyetoran.

Berikut flowchat alur sistem yang berjalan:

Tabel 3.1 Flowchat sistem yang berjalan

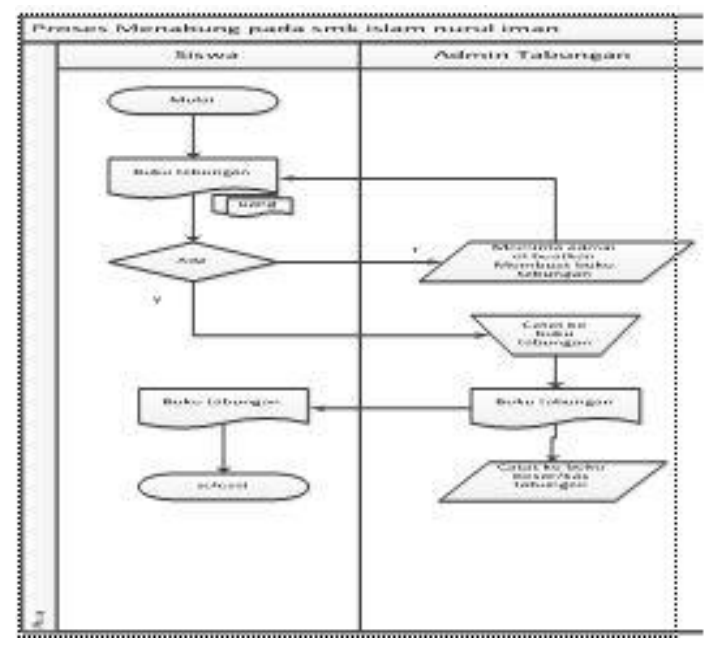

\subsubsection{Kelemahan Sistem Berjalan}

Dari sistem yang berjalan, dapat di simpulkan kelemahan-kelemahan yaitu:

- Banyak kemungkinan penjumlahan yang keliru karna input tabungan masih konfensional/manual.

- Pencarian data siswa yang menabung yang relatif sulit

- Buku tabungan siswa rawan hilang

3.6 Usulan Sistem Baru 
3.6.1 UML (Unified Modelling Language)

3.6.1.1 Rancangan Use Case Diagram.

Use case adalah abstraksi dari interaksi antara sistem dan aktor. Use case bekerja dengan cara mendeskripsikan tipe interaksi antara user sebuah sistem dengan sistemnya sendiri melalui sebuah cerita bagaimana sebuah system dipakai Adapun diagram usecase yang telah penulis rancang adalah sebagai berikut:

Tabel 3.2 UseCase Diagram

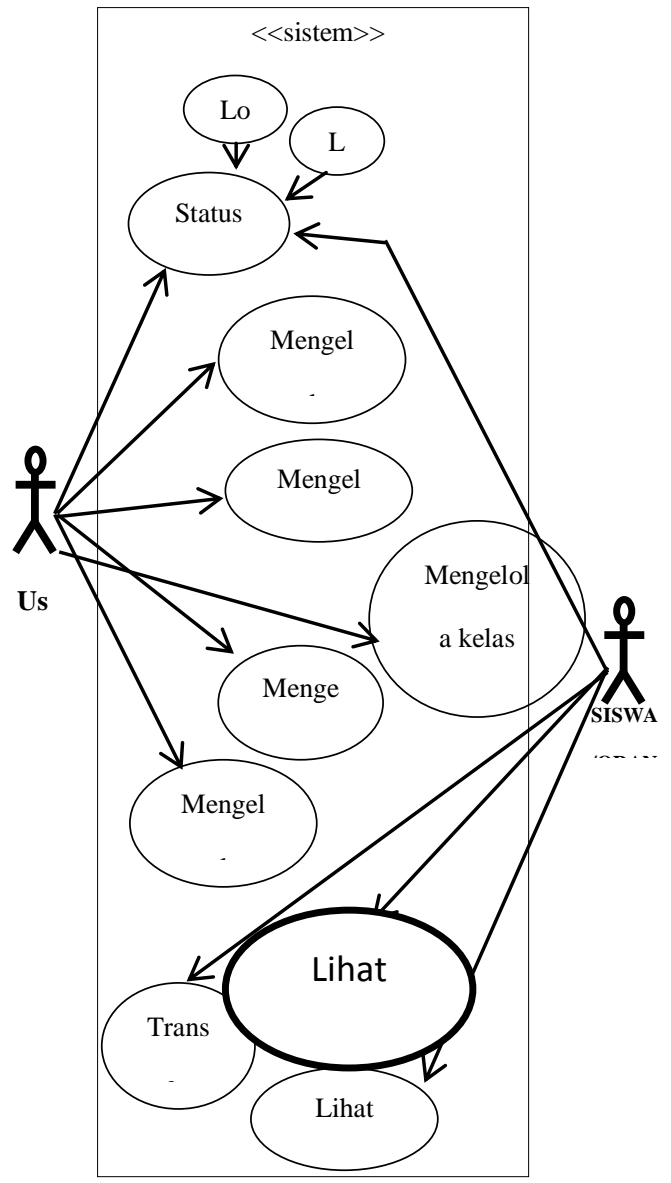

3.6.1.2 Rancangan Class Diagram

Class adalah deskripsi kelompok obyek-obyek dengan property, perilaku (operasi) danrelasi yang sama. Sehingga dengan adanya class diagram dapat memberikan pandangan global atas sebuah system. Hal tersebut tercermin dari class- class yang ada dan relasinya satu dengan yang lainnya. Berikut disajikan class diagram yang dirancang untuk penelitian ini :

Tabel 3.3 class Diagram

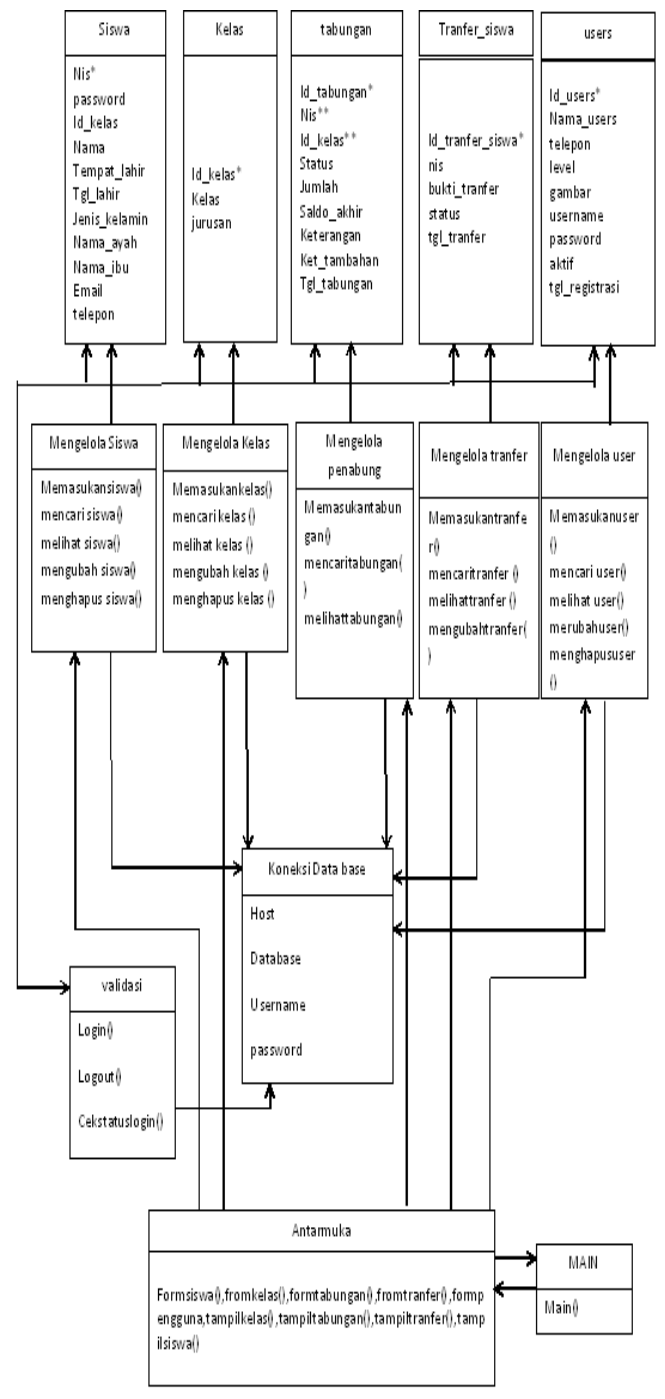

4. HASIL DAN PEMBAHASAN

4.1 Hasil Penelitian

Dari penelitian ini, penelti mendapatkan hasil bahwa pada SMK islam nurul iman lampung timur yang jumlah siswanya tidak sedikit sering kali mengalami masalah dalam hilangnya buku tabungan siswa, proses transaksi tabungan baik dalam pencatatan transaksi maupun dalam peyusunan laporan tabungan. Disamping itu wali siswa sangat perlu memonitoring tabungan anak mereka, sehingga tidak adanya kesalah paham ataupun tindakan yang menyimpang dalam hal tabungan-menabung yang dilakukan antara pihak siswa dan sekolah.

Dengan hasil penelitian tersebut, penulis merancang bangun sistem informasi dalam bentuk aplikasi tabungan siswa yang dapat meminimalisir terjadinya kesalahan dalam proses transaksi dan 
penyusunan laporan tabungan serta adanya transparansi data yang diperlukan oleh pihak sekolah ataupun wali siswa yang dapat diakses dimana saja dan kapan saja, karena sistem tersebut sudah tersambung ke jaring internet.

\subsection{Pembahasan Hasil Program}

Pada saat ini, SMK islam nurul iman sering kali mengalami masalah dalam sering hilangnya buku tabungan siswa, pencatatan transaksi tabungan, siswa maupun wali siswa sangat kesulitan mencari informasi tentang transaksi tabungan, karena sistem yang digunakan selama ini masih menggunakan sistem secara manual Masalah yang sering terjadi yaitu sulitnya mendapatkan informasi tentang Tabungan Siswa SMK islam nurul iman dengan cepat. Sehingga mengakibatkan adanya kesalahan baik dalam transaksi maupun pelaporannya.

\subsubsection{Menu Login}

Menu login merupakan tampilan yang akan muncul saat pertama kali kita menjalankan Aplikasi Pengolahan Data. Untuk menjalankan program ini makatahap yang harus di lakukan ialah :

- Pastikan komputer dalam keadaan hidup atau standby dan jaringan tersambung ke internet

- Buka browser chrome

- Ketikan alamat website tabungan siswa sesuai domain pada address bar kemudian klik enter.

Secara otomatis akan tampil Halaman Login. Berikut tampilan menu login admin:

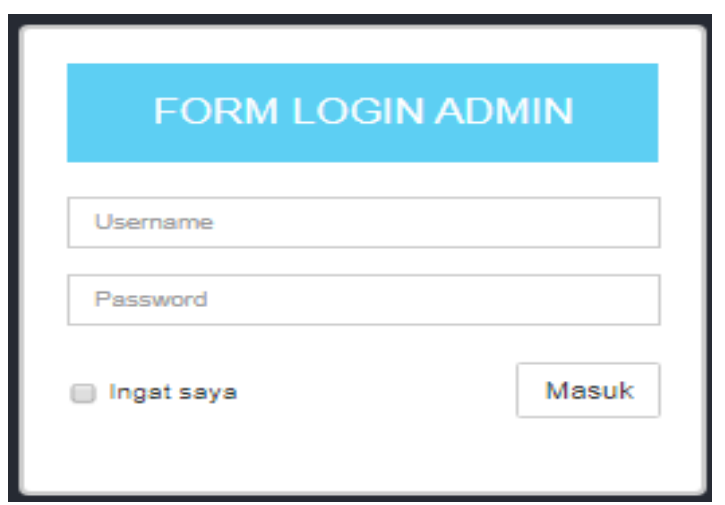

Gambar 4.1 Form Sub Menu Login

\subsubsection{Form Menu Utama}

Akan tampil Menu Utama ketika telah login terlebih dahulu,

Berikut ini merupakan tampilan utama aplikasi setelah melakukan login sebagai administrator :

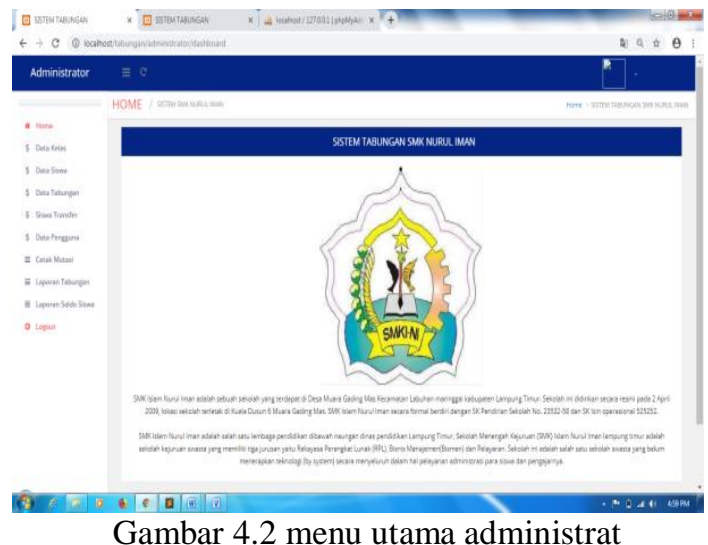

\subsubsection{Form Tampilandata kelas}

Tampilan ini digunakan untuk melihat data kelas.

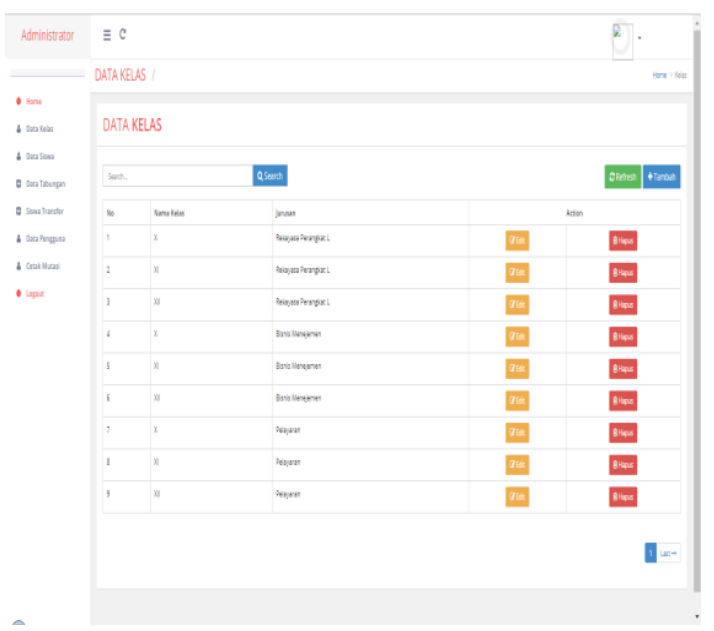

Gambar 4.3 tampilan data kelas

Jika ingin menambahkan data kelas, pilih botton "tambah" pada bagian data kelas

Dalam kasus ini penginputan kelas terdapat 3jurusanmasing-masing tingkat yaitu kelas $\mathrm{X}$ sampai dengan kelas XII. Berikut merupakan tampilan menu input kelas :

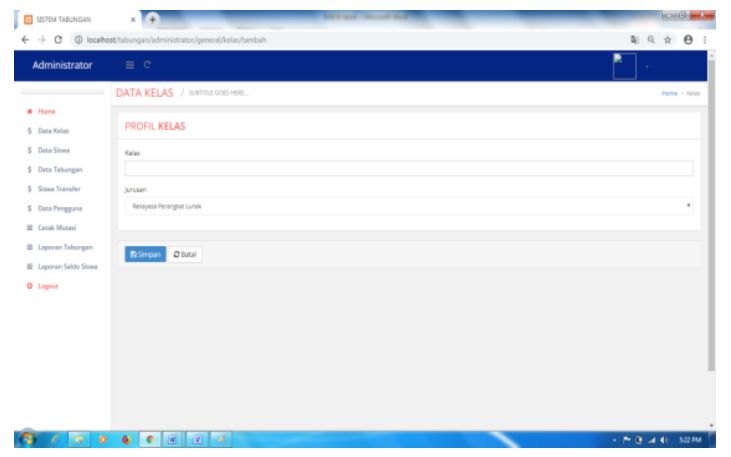

Gambar 4.4 tampilan input kelas dan jurusan 


\subsubsection{Form Tampilan data siswa}

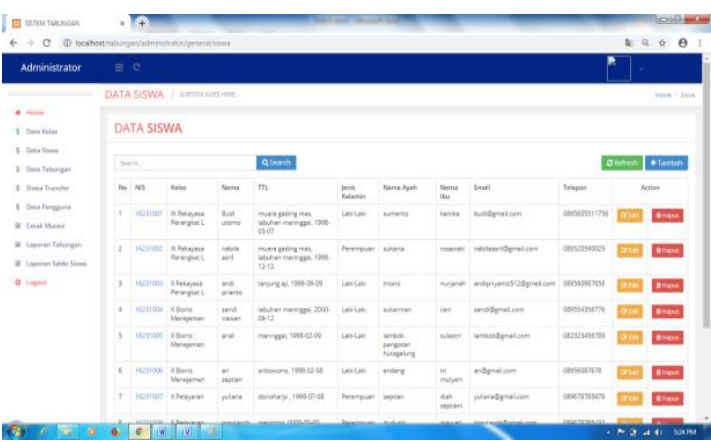

Gambar 4.5 tampilan data siswa

Menu tampilan ini digunakan untuk melihat data siswa, memasukan transaksi menabung dan memasukan siswa yang baru akan menabung pertama kali.

Jika ingin memasukan transaksi tabungan bagisiswa yang sudah terdaftar, tuliskan nis siswa yang menabung di kolom pencarian lalu pilih botton "search" setelah itu maka akan tampil data siswa tersebut, kemudian klik pada nis siswa maka akan tampil sebagai berikut:

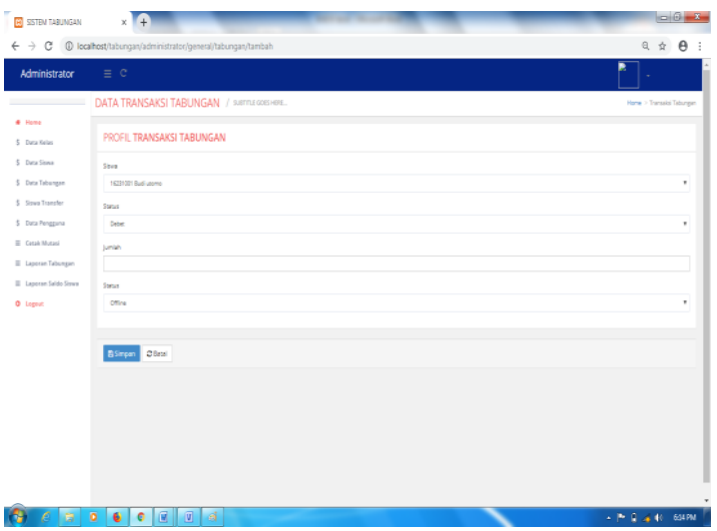

Gambar 4.6 input transaksi tabungan

Di form transaksi ini Nama siswa akan otomatis terpilih sesuai Nis siswa yang menabung,Pilih status "debet" yang berarti menabung "kredit" yang berarti mengambil tabungan dan isikan jumlah nominalnya, Kemudian jika siswa/orang tua menabung melalui sistem transfer untuk menabung maka di status tabungan pilih online, jika siswa dating langsung kesekolah untuk menabung maka di status tabungan pilih "ofline" Lalu pilih button "simpan" maka akan tampil data tabungan seperti gambar di bawah ini:

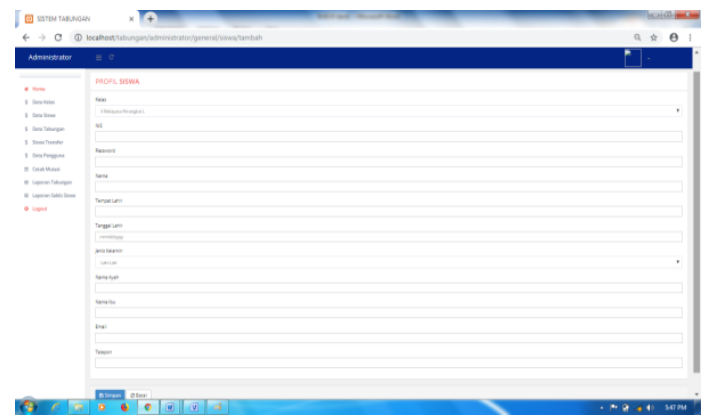

Gambar 4.7 tampilan data tabungan

Kemudian jika menambahkan siswa yaitu dengan cara memilih botton "tambah" pada form tampilan data siswa maka akan tampil seperti gambar di bawah ini:

Berikut tampilan dalam menginput data siswa calon menabung :

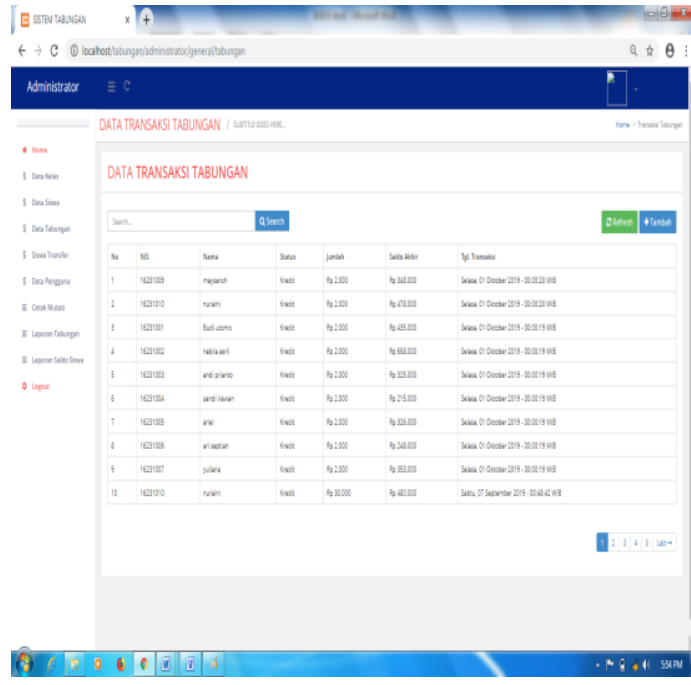

Gambar 4.8 tampilan input siswa

setelah itu kita isi data dengan lengkap dan jika sudah selesai mengisi data maka pilih button "Simpan" maka data siswa akan secara otomastis tersimpan.

4.2.5 Form tabungan

Berikut tampilannya

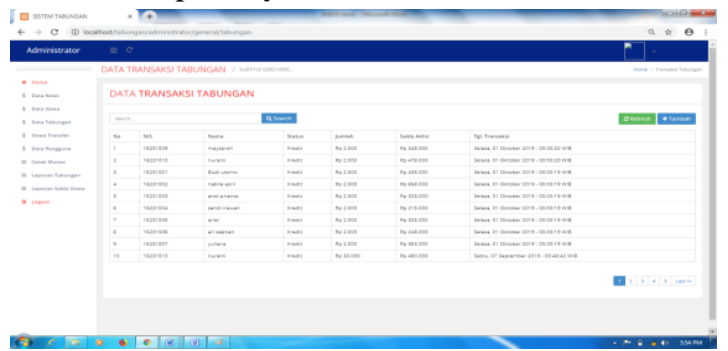


Gambar 4.9 Form Input data siswa

Pada form ini di gunakan untuk melihat transaksi transaksi yang menabung.

\subsubsection{Data siswa transfer}

Tampilan ini digunakan untuk melihat data bukti transfer darisiswa/orang tua

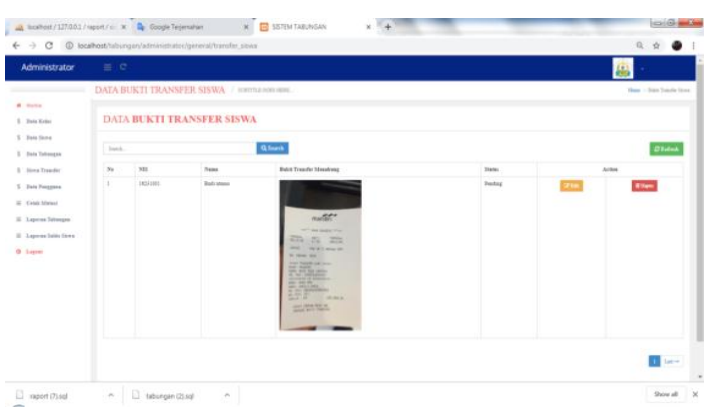

Gambar 4.10 data siswa transfer

\subsubsection{Form data pengguna}

Pada form ini digunakan untuk merubah data pengguna.

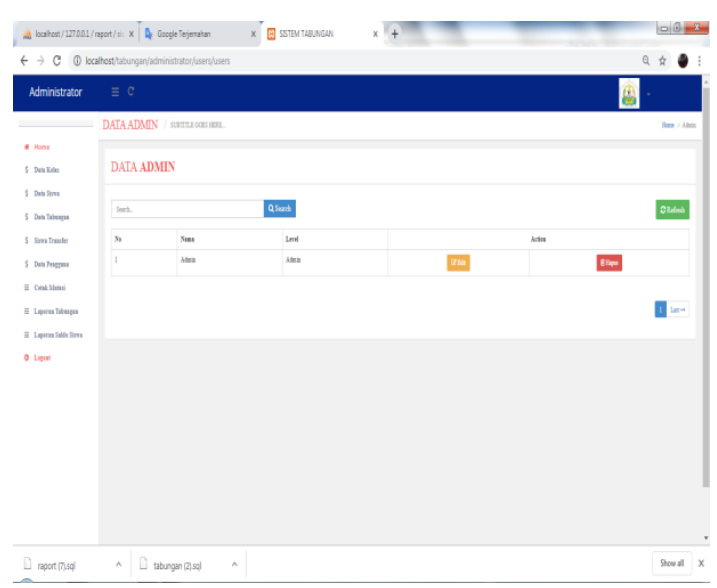

Gambar 4.11 Form data pengguna

4.2.8 Form cetak laporan mutasi tabungan siswa

Berikut tampilan form nya :

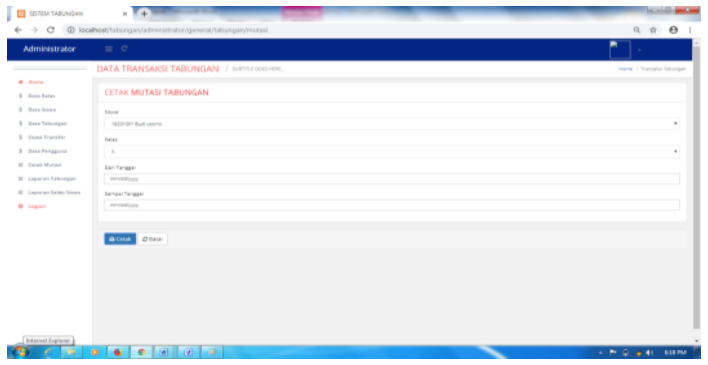

Gambar 4.12 Tampilan Form Mutasi Tabungan

4.2.9 Form cetak laporan tabungan per periode. Berikut tampilannya

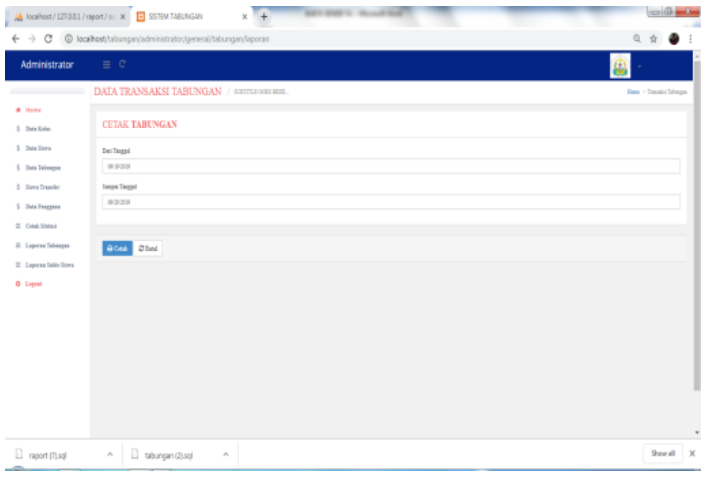

Gambar 4.13 form cetak laporan per periode

Setelah di input dari tanggal sampai tanggal kemudian pilih botton "cetak" maka akan tampil data laporan sebagai berikut:

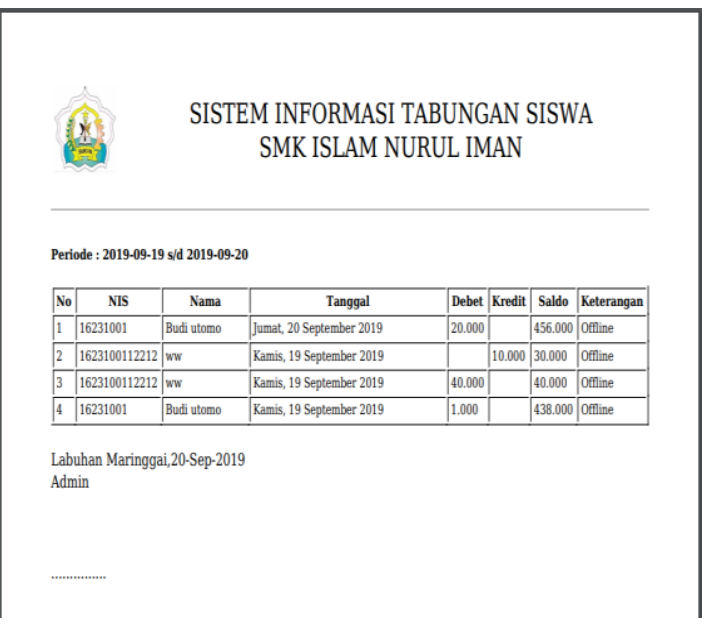

Gambar 4.14 hasil laporan per periode

\subsubsection{Form Laporan Tabungan perkelas}

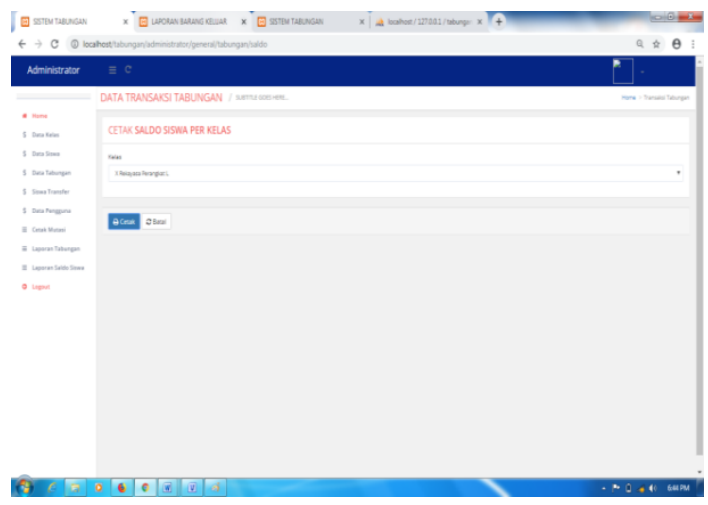

Gambar 4.15 Form laporan tabungan perkelas 
Setelah itu pilih kelas yang akan di cetak kemudian pilih botton "cetak" maka akan tampil data laporan sebagai berikut:

\subsubsection{Form Laporan Tabungan \\ 4.2.12 perkelas}

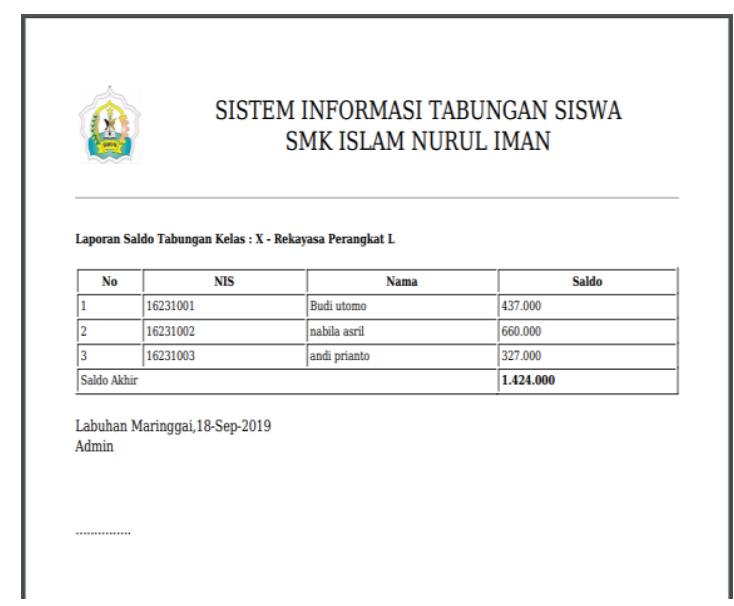

Gambar 4.14Laporan Tabungan Shortir Per Kelas

\subsubsection{Form Laporan Tabungan Per Siswa}

Gambar 4.16 hasil laporan perkelas

2.2.12 tampilan login siswa Siswa login berdasarkan nis dan password nya

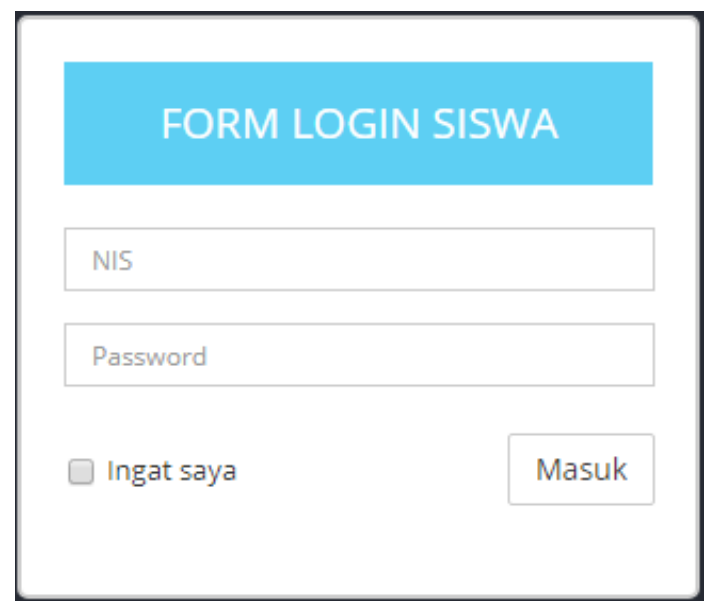

Gambar 4.17 login siswa

4.2.13 Tampilan Home Siswa

Akan tampil Menu Utama ketika telah login terlebih dahulu,Berikut ini merupakan tampilan utama aplikasi setelah melakukan login sebagai siswa

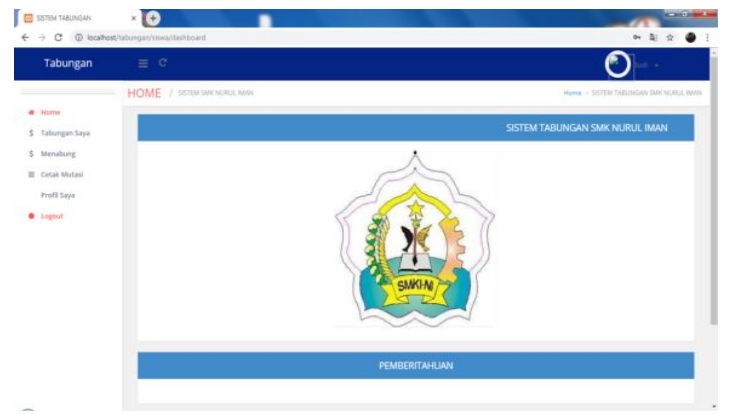

Gambar 4.18 tampilan home siswa

4.2.14 tampilan halaman data tabungan saya Di pergunakan untuk para siswa melihat saldo tabungannya dan riwayat transaksi tabungannya.

Berikut tampilannya.

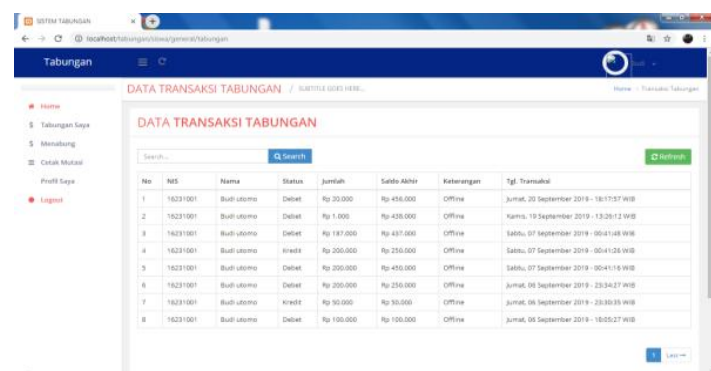

Gambar 4.19 tampilan halaman data tabungan saya

4.2.15 tampilan halaman data menabung.

Di pergunakan untuk siswa /orang tua untuk menabung dengan cara mentranfer kenomer rekening yang tertera pada sistem dengan cara memasukan bukti transfer.

Berikut tampilan nya.

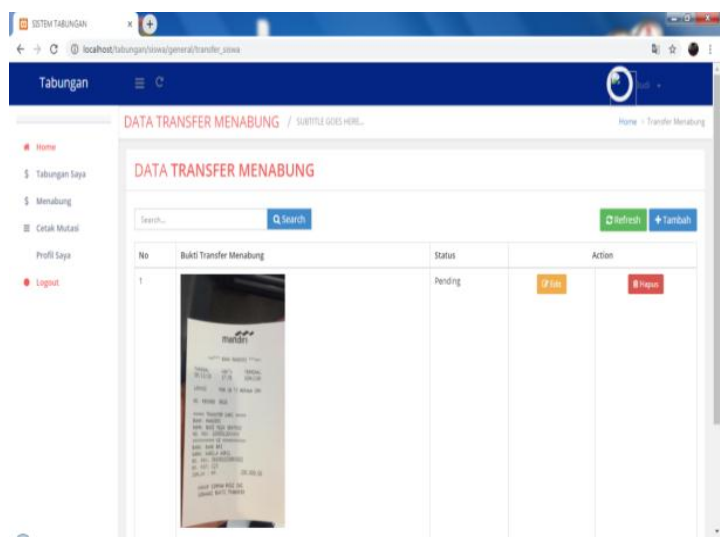

Gambar 4.20 tampilan halaman data menabung 
Jika siswa/orang tua mau upload bukti transfer pilih botton "tambah" dan akan muncul form sebagai berikut:

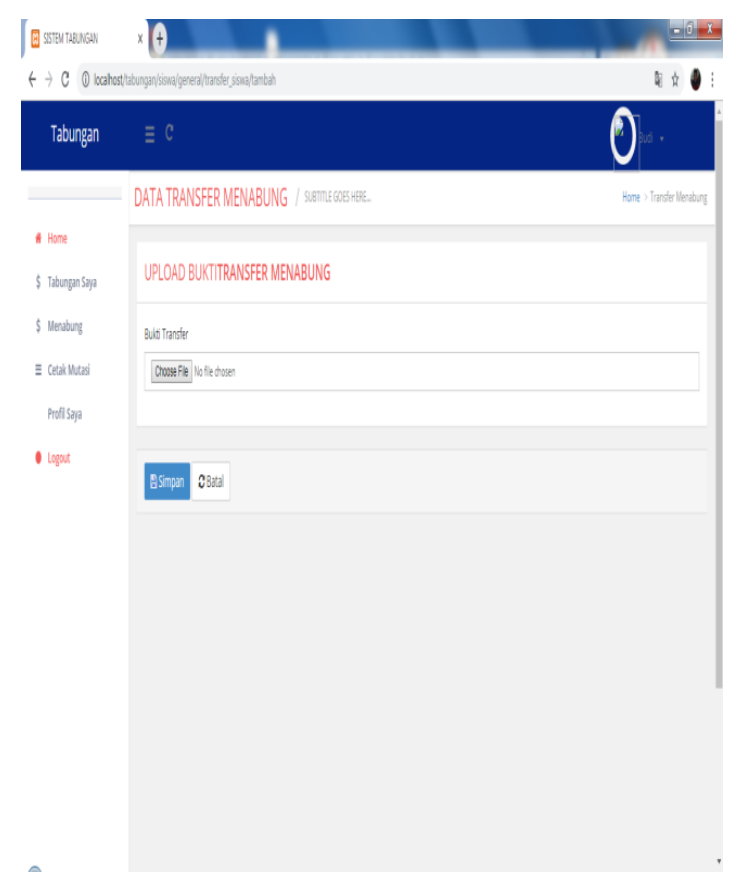

Gambar 4.21 tampilan halaman upload bukti tranfer

4.2.16 tampilan halaman data cetak mutasi laporan.

Berikut tampilannya:

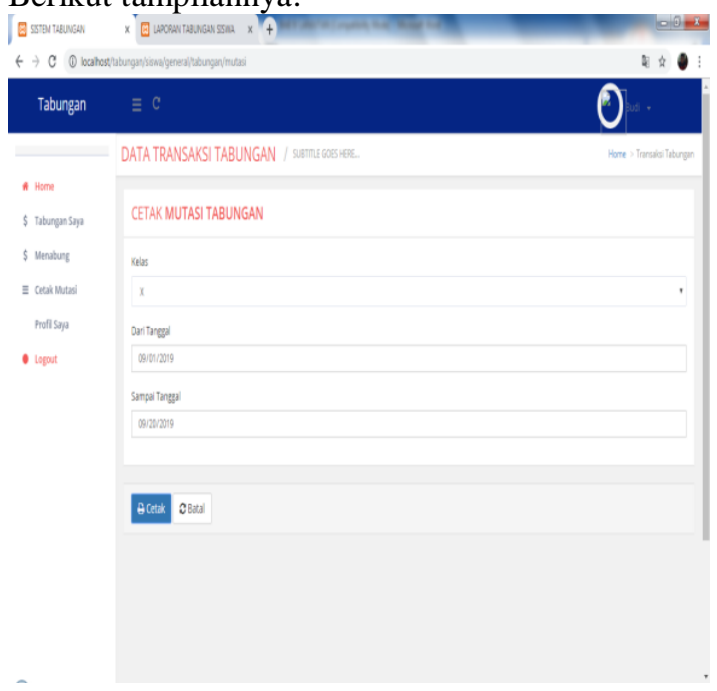

Gambar 4.22 tampilan halaman data cetak mutasi laporan.
Setelah itu pilih kelas, pilih dari tanggal sampai tanggal yang akan di cetak kemudian pilih botton "cetak" maka akan tampil data . laporan sebagai berikut:

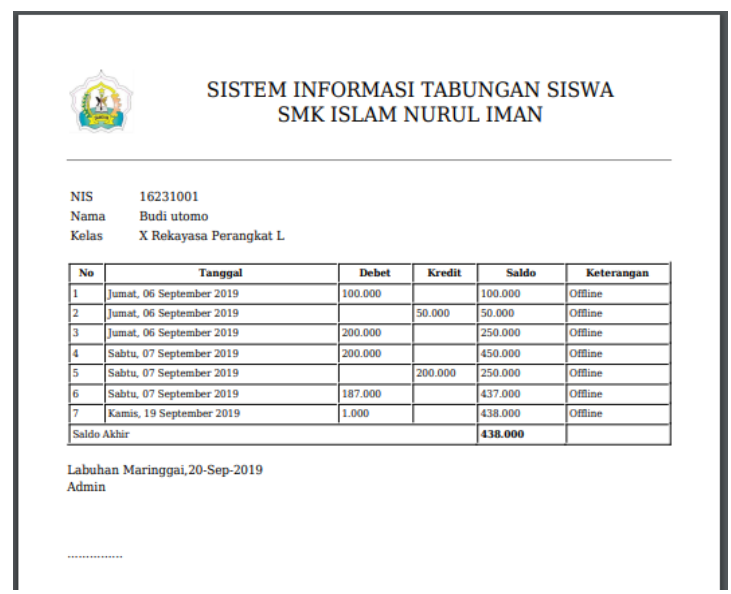

Gambar 4.23 tampilan halaman data cetak laporan.

\subsubsection{7 tampilan halaman frofil saya}

Di pergunakan untuk mengubah password maupun data lainnya

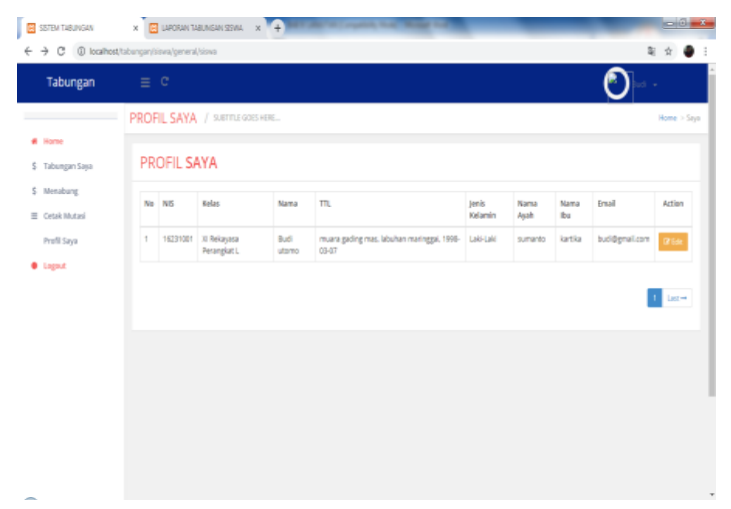

Gambar 4.24 tampilan halaman frofil saya

\section{KESIMPULAN DAN SARAN}

5.1 Kesimpulan

Dari uraian pembahasan penelitian diatas, maka peneliti dapat mengambil kesimpulan sebagai berikut :

1. Dengan menggunakan aplikasi berbasis komputerisasi, akan mempermudah dalam mencari informasi Dan juga dapat membantu penyampaian informasi transaksi secara detail kepada siswa maupun wali siswa.

2. Dengan adanya aplikasi berbasis komputerisasi juga sangat meminimalisirkan dalam hilangnya buku tabungan siswa, kesalahan dalam pencatatan data apabila 
penyetoran dengan jumlah transaksi yang banyak,

\subsection{SARAN}

Dari pembahasan penelitian di atas, peneliti juga memberikan saran sebagai berikut :

1. Sebaiknya dalam proses transaksi tabungan siswa SMK islam nurul iman tidak lagi menggunakan sistem yang lama, melainkan menerapkan sistem komputerisasi yang dilengkapi dengan perancangan database seperti yang peneliti usulkan, agar data yang dihasilkan lebih akurat.

2. Rancangan program ini perlu terus dikembangkan sesuai dengan kebutuhan atau jika ada perubahan sistem tabungan siswa SMK islam nurul iman.

3. Sistem yang dibuat oleh peneliti ini masih jauh dari kata sempurna, maka peneliti membutuhkan kritik dan saran untuk pengembangan lebih jauh.

\section{DAFTAR PUSTAKA}

[1] Senn, James A. 1989. Analysis and Desaign of Information Sstes, Portsmout, $\mathrm{NH}$, U.S.A : McGraw-Hill Companies.

[2] Toto Suharto, Filsafat Pendidkan Islam, Jakarta: Ar-Ruzz, 2006

[3] Azza, a.b. (2016). Sistem Informasi Pengolahan Data Tabungan Siswa MI Bahrul Ulum Berbasis Web Mobile Menggunakan Codeigniter dan Bootstrap. Jurnal Teknik A, 2.

[4] Presiden RI, (1998), Undang-Undang Republik Indonesia Nomor 10 Tentang Perbankan. Jakarta.

[5] Irawati. (2018). Prosedur Pelayanan Tabungan Britama Junior Pada PT. Bank Rakyat Indonesia(Persero)

[6] Presiden RI, (2013), Undang-Undang Republik Indonesia Nomor 20 Tentang Sistem Pendidikan Nasional. Jakarta.

[7] Purnama. (2014). Perancangan Program Aplikasi Tabungan Siswa Sekolah Dasar Negeri Cipancar IV dengan menggunakan pendekatan Metodologi
Rapid Application Development. Jurnal Algoritma Vol. 11 No.1 Garut:STT Garut, 18.

[8] Destiniar, Irwansyah, Dedi, \& Tomhart. (2012). Analisis Website Badan Teknologi Nuklir Nasional (Batan) Bandung. 5-7.

[9] Ardhy, Ferly. "Sistem Pengamblan Keputusan Pemilihan Bibit Jagung Dengan Metode Analytical Hierarchy Process (Ahp) Pada Toko Abadi Jaya Lampung Timur." Jurnal Informasi dan Komputer 6.2 (2018): 73-80. 